\title{
Effect of Exchange Rate on Trade Balance in Major East African Countries: Evidence from Panel Cointegration
}

\author{
Kedir Bekeru Genemo \\ Department of Statistics, Jimma University, Jimma, Ethiopia \\ Email address: \\ keder.beker@gmail.com, keder.beker@yahoo.com \\ To cite this article: \\ Kedir Bekeru Genemo. Effect of Exchange Rate on Trade Balance in Major East African Countries: Evidence from Panel Cointegration. \\ European Business \& Management. Vol. 3, No. 6, 2017, pp. 95-104. doi: 10.11648/j.ebm.20170306.11
}

Received: September 25, 2017; Accepted: October 26, 2017; Published: November 20, 2017

\begin{abstract}
This paper attempts an empirical investigation of the impact of exchange rate devaluation on major east African countries trade balance using the panel co-integration and panel group fully modified least square estimation technique from 1990-2014. Whether exchange rate devaluation improves or worsens trade balance has been at the centre of literature debate over time with varying empirical evidences for developed and developing nation. The results indicate that there exist a longrun stationary relationship between trade balance and its determinant- foreign and domestic income, nominal exchange rate as employed in the study. The research major findings include; nominal exchange rate induces inelastic and significant relation on trade balance in the long run. From this, the paper concludes that the trade balance deteriorate with increasing depreciation of exchange rate (as a value effect in east African countries). Again, it found that the coefficient of domestic income is negative and significant implying that the booming of real domestic income increases the purchasing power of their household to import more resulting trade deficit in the long run. Moreover the paper found that inelastic coefficient of nominal exchange rate in line with the theoretical Marshall-Lerner condition i.e. "the demand for import and export is inelastic then devaluation would further increase the trade deficit" [21]. Therefore based on the empirical findings the researcher recommends that the policy maker of these countries should take emphasis not to devaluate exchange rate more and selecting countries with higher income to make import and export elastic and improve trade balance in the long run.
\end{abstract}

Keywords: Devaluation, Panel Co-Integration, FMOLS

\section{Introduction}

\subsection{Background of the Study}

In an open market economy, trade balance is considered as one of the major component of GDP. However, the problem is that this major component may contribute depressingly into GDP when payments to the rest of the world greater than receiving from the rest of the world. This prone to deficit in the trade balance which is commonly faced most of the developed and developing countries. The exchange rate considered, as a tool for the regulation of trade balance, which ultimately affects national income, and welfare of a nation and hence the size on the effects of changes in exchange rates is critical information for trade balance and exchange rate policymakers [8]. It is also emphasized development in macroeconomic analysis for open economy that the reaction of the exchange rate fluctuations on the trade balance is important to understand because of the possibility to target the trade balance to get the optimal national income [4].

One of the policy used is currency devaluation under free exchange rate regime which expected to eliminate persistent trade balance deficits by decreasing prices of the home country's exports abroad and increase the price of imports at home, inducing export quantity to rise and import quantity to decrease, thereby influencing the trade balance certainly. However, the impact of the exchange rates can be different in the long run compared to the short-run due to the slow adjustment of the trade quantity to the new exchange rate level i. e. J-curve theory [4]. This theory depict that after a real depreciation or devaluation of exchange rate the trade balance expected to deteriorate first due to increased import value in terms of domestic currency and sticky prices. Subsequently, over time, the volume of export will increase and the volume of import will decrease when adjusting for 
the new exchange rate and the trade balance will then improved.

Depending on this economic theory and advice from different research center including international monetary fund and World Bank, many of developing countries including sub-Saharan African countries are depreciating their currency toward trading partner since 1990. However, there could not seen improvement in trade balance and the reason why this is so is still unclear. Therefore, this paper mainly intended to clarify the reason behind currency depreciation and trade balance deterioration putting emphasis in major east African countries such as Ethiopia, Kenya, Tanzania, Uganda, and Rwanda.

\subsection{Statements of Problem}

Many of Sub-Saharan African countries have been experiencing trade deficits in their economy. One of the reasons for such performance is the poor economic integration and strategies that have adopted by these countries in their economic reforms and most of these countries usually depends on certain specific primary products for their exports and import a lot of the manufactured goods hence huge trade deficit in their economy [25]. Ethiopia, Uganda, Tanzania, Rwanda, and Kenya are not an exception of this group of countries that have implemented several economic policies with the purpose of improving trade balance and promote its economic development.

Besides, studies examined the relationship between exchange rate devaluation and trade balance in emerging countries by [13] showed that, there was Cointegration between real effective exchange rate and export-import of emerging economies in the long run. He said in his paper that in total 5 of 22 emerging countries (Bolivia, Cameroon, Dominica, Gabon and Mexico) have both long term and short term relationship and concluded with depreciation of currency improved trade balance for only five countries. However [2] Studied the impact of currency devaluation on Nigeria trade balance using the Johansen Cointegration and variance decomposition methods on data spanned from 19702010 and found an inelastic and significant relation between trade balance and its Exchange rate in the long run.

In short, even though trade theory assert that devaluation of currency plays a vital role in improving trade balance of a country, empirical finding showed misleading result. If the trade is open, it could hinder the exports in short run but exports might increase in the long run (in line with theory), but putting low level of imports may cause a decline in exports if import goods is an input for production of export goods (orthogonal idea to theory). Similarly, a low level of exports may cause a decline in imports due to lack of foreign exchange. Therefore, in this paper the researcher intension is to investigate clear idea on the behavior of exchange rate devaluation and trade balance in selected East African countries and makes apparent the nonconformity of relationship in the variable and to show how well worked devaluation policy in these countries.

\subsection{Objectives of the Study}

The general objective of this research paper is to scrutinize the impacts of exchange rate devaluation on trade balance in major East African countries. More specifically, the study attempts:

1. To show how well devaluation of currency improve the trade balance for the countries under study.

2. To examine empirically the joint long run effect of exchange rate on trade balance in panel of these countries.

\subsection{Significance of the Study}

Quantifying long run relationship of the trade balance and exchange rates is important, because if stable long run does not exist depreciating of exchange rate does not seem to be a reasonable way of improving countries trade balance competiveness. Therefore, this study is significant because it will guide all countries under consideration in their formulation of monetary and supervisory policies. This paper may also help researchers or policy makers who are concerned with the economic situation mainly developing east African countries.

\subsection{Organization of the Paper}

The paper is organized in 5 chapters. The first chapter presents introductory part of the study. The second chapter deals with the review of theoretical and empirical literature. The third chapter presents data and methods. The fourth chapter presents empirical results. The last chapter presents conclusion and policy implications.

\section{Review of Related Literature}

\subsection{Theoretical Literature Review}

The exchange rate affects the competiveness of the commodities that a country exports. Different theories that forwarded in this part reflect how a country experiences a depreciation of exchange rate and its effects on the trade balance. The concentration of this paper is based on real exchange rate because much literature used nominal exchange rate to see the improvements of trade balance. Two approach were discussed here are elasticity and absorption approach.

\subsubsection{The Elasticity Approach}

This approach provides an analysis of what happens to trade balance when a country devalues its currency and conditions that must prevail in the foreign exchange market for a devaluation or depreciation of the currency to improve the trade balance starting from equilibrium [29]. Under this assumptions, the condition for a devaluation to improve the trade balance, which directly contributes to the improvement of the balance of payments (starting from equilibrium), is known as the Marshall-Lerner condition. It states that devaluation will improve the balance of payments on trade balance if the sum of the foreign price elasticity of demand 
for exports $\left(e_{x}\right)$ and domestic price elasticity of demand for imports $\left(e_{m}\right)$ exceeds unity, in absolute value, i. e. if:

$$
\left|e_{m}+e_{x}\right|>1
$$

Any combination of price elasticity of demand for exports and imports will improve foreign exchange earnings provided that they sum to greater than unity. In general, there is highly held view that this approach made very simplistic assumption and it is by no means certain that in practice the elasticity condition are satisfied, or that, by the time they are satisfied the competitive advantage gained by depreciation has not been eroded by the induced price rise.

\subsubsection{The Absorption Approach}

The major purpose of the absorption approach is to integrate the balance of payments with the functioning of the total economy in a general equilibrium framework, in which balance of payments disequilibrium on current account viewed as the outcome of the difference between decisions to produce and spend, or to save and invest [11]. Taking the national income identity:

$$
\mathrm{Y}=\mathrm{C}+\mathrm{I}+\mathrm{G}+\mathrm{X}-\mathrm{M}
$$

Rearranging as:

$$
\mathrm{TB}=\mathrm{Y}-\mathrm{A}
$$

That is, trade balance is the difference between income and absorption. Alternatively, since $\mathrm{Y}-\mathrm{C}-\mathrm{G}$ is savings ( $\mathrm{S}$ ), equation (3) can be rewritten as:

$$
\mathrm{TB}=\mathrm{S}-\mathrm{I}
$$

Similarly, the absorption approach can be spelled out using the leakage -injection terminology [11]. Thus, $\mathrm{S}+\mathrm{T}+\mathrm{M}=\mathrm{I}+\mathrm{X}+\mathrm{G}$ and on rearrangement $(\mathrm{S}-\mathrm{I})+(\mathrm{T}-\mathrm{G})=\mathrm{X}-\mathrm{M}$. Where $\mathrm{T}$ is tax and the other variables are as defined above. Within this framework, devaluation can be evaluated in terms of whether it raises income $(\mathrm{Y})$ relative to absorption $(\mathrm{A})$, or saving (S) relative to investment (I). Policy to raises $\mathrm{Y}$ is termed expenditure-switching policies includes tariffs, import quotas, export subsidies and devaluation. Policies to reduce A are termed expenditure reducing policies and include higher taxes, lower government expenditure, higher interest rates [23-24]. Taking the difference of equation (4), we have:

$$
\mathrm{dTB}=\mathrm{dY}-\mathrm{dA}
$$

Devaluation will have direct effects on income (dY), direct effects on absorption (dA), and indirect effects on absorption working through changes in income whose magnitude depends on marginal propensity to absorb, $\alpha$ (determined by the propensity to consume and invest) ( $\alpha \mathrm{dY})$. Thus, the change in total absorption $\mathrm{dA}$ is given by:

$$
\mathrm{dA}=\alpha \mathrm{dY}+\mathrm{dAd}
$$

Substituting (5) in equation (6):

$$
\mathrm{dTB}=\mathrm{dY}-(\alpha \mathrm{dY}+\mathrm{d} \overline{\mathrm{A}})=\mathrm{dY}(1-\alpha)-\mathrm{d}
$$

Equation (6) reveals that there are three factors to be considered in the analysis of the impact of devaluation in absorption approach. (1) How does devaluation affect income? (2) What is the value of $\alpha$, the propensity to absorb, and (3) how does devaluation affect absorption directly?

Finally, as discussed above the effects of devaluation are many, often conflicting and indeterminate. It should noted that equations (6) and (7), which portrays the balance of payments as the difference between income and expenditure, or savings and investment, are derived from the national income identities, and causation must never be inferred from these identities.

\subsection{Empirical Literature Review}

Many empirical analyses, both multi-country panel regressions and econometric models applied to individual countries conducted to show how exchange rate devaluation affects the trade balance of developing and developed countries. For instance, [13] studied the effect of exchange rates on exports and imports of emerging countries using panel Cointegration method for the period of 1985-2012. He showed that, there was co-integration between real effective exchange rate and export-import of emerging economies in the long run. In total 5 of 22 emerging countries (Bolivia, Cameroon, Dominica, Gabon and Mexico) have both longterm relationship and short term parameters and are statistically significant and concluded that exchange rate effects support the theoretically expected results for the selected emerging countries.

Again [12] investigated the effects of devaluation on the trade balance in Malawi and South Africa using a vector error correction model (VECM and generalized impulse response functions to trace the response of the trade balance to the shocks in the exchange rate. He found the existence of a long-run equilibrium positive relationship between trade balance and the real effective exchange rate indicating that a real depreciation will improve the trade balance in the long run for both Malawi and South Africa. Study on the effect of real exchange rate on India's bilateral trade balance with her 89 trading partner countries. The study used FMOLS method, a non-parametric heterogeneous panel Cointegration technique, for removing the endogeneity problem among regressors. They found an existence of a long-run relationship between India's trade balance and real exchange rate, and concluded that India's trade balance would improve with the real depreciation of exchange rate in the long run but deteriorate with the rise of India's real income.

Besides [16] study examined the relationship between the trade balance and the real exchange rate in two regions of the western hemisphere: Central America, the Caribbean, and a bilateral approach between a panel of 12 countries from the region and each of four industrialized countries; The US, Britain, France and Japan. After a brief review of the history of the trade balance and of individual cases of devaluation, he employed OLS and the Fisher-Johansen Panel 
Cointegration technique, to investigate the existence of a stable long-term relationship between bilateral currency depreciations, income levels and the trade balance for the panel. He found currency devaluations do affect positively the trade balance.

However, investigation on the effects of exchange rate on the foreign trade of some selected African countries in a panel Cointegration approach [3] found that export and import are inelastic to changes in exchange rate. It follows that depreciation of currencies in the region may not have the expected results in view of the composition of our exports. In the same vein, depreciation would only aggravate imports of the region. Thus, in light of the findings, a policy of exchange rate stability, which hinges on extensive institutional and technological capacity as well as the maintenance of comprehensive coherent macroeconomic packages remains a critical factor in ensuring that exchange rate policy performs its central role as a trade facilitation tool.

In the same way [5] investigated the impact of real exchange rate depreciation on balance of trade of Pakistan with her 13 largest trading partners. The study used disaggregated quarterly data of 1980 to 2003 on a bilateral basis to avoid the aggregation bias problem. The study employed two econometric techniques for this rationale, $i$. $e$. bound testing technique and Johansen's Cointegration techniques. He found that almost half of the trading partners including two largest trading partners, $i$. e. China and UAE hurt by depreciation of Pakistan's currency. In addition, he said Cointegration approach did not provide any significant long run impact on bilateral trade balance in response to real exchange rate depreciation, which proves no indication in favor of J-curve phenomenon in Pakistan.

Besides, study on the relationship between Trade Balance and Exchange Rate in Ethiopia explores impulse response VAR and VECM [1]. He concluded that trade balance in Ethiopia after real depreciation of currency follows J-curve patter. He said that estimates suggests real depreciation in the first three years trade balance deteriorates ('short run') and subsequently improves. The forecast error variance decomposition for each variable reveals the proportion of the movement in variable due to its own shocks versus the shocks in other variables. The variance decomposition of trade balance reveals that changes in its own shock, trade balance is the predominant source of variation in the logarithm of trade balance. The result showed own series shock of trade balance explain most of the forecast error variance of the series in both based on VAR and VECM.

In the last, [25] studied focusing on the Analysis of the Main determinants that have an impact on trade balance. Specifically his study focused on the main cause of Trade deficit in Tanzania by analyzing the impact of Foreign Direct Investment, Human Capital Development, Household Consumption Expenditure, Government Expenditure Inflation, Natural Resources Availability, Real Exchange Rate, and Foreign Income and Trade Linearization exploring Ordinary Least Square method econometric analysis spanned 1980-2012. It is quite apparent that despite theoretical literature said that currency devaluation improve trade balance in the long run, empirical literature showed mixed results for both developed and developing countries as well as panel and single country. The literature on the subject suggests that the trade balance improves with devaluation in some cases, while quite the opposite holds true in other cases. It expected that the current study make a substantial contribution to the debate on this important issue by shedding some light on the phenomenon in major east African countries for the last 25 years.

\section{Methodology}

\subsection{Source of Data}

Secondary data used in this study. The balanced panel consists of annual data for imports and exports, real gross domestic product, and real effective exchange rate, and real world income for five selected east African countries, namely Ethiopia, Kenya, Tanzania, Rwanda and Uganda for the period of 1990-2014 measured in US dollars considered in this study. The data are gathered and verified from united nation Statistics database, united nation conference on trade and development database. In addition, selection of the data and countries was based on availability of data and on geographical area respectively.

\subsection{Model Specification}

In this paper the researcher pooled cross-section and time series data to study relationships between trade balance and real effective exchange rate following the convention adopted by the model from [16] based on Keynesians trade balance approach. Turning to the following equation:

$$
T B=f\left(E, Y, Y^{*}\right)
$$

Where: TB is trade balance and factors that influence trade balance includes, exchange rate, domestic income and world income. Among these four time-varying explanatory variables employed in this analysis, TB which is $(\mathrm{TB})$ it $=(\mathrm{X} / \mathrm{M})$ it measured as the ratio of country i's exports to the rest of the world and country i's import from the rest of the world. $\mathrm{Y}_{i t}$ (RGDP country i) Moreover $\mathrm{Y}_{i t}$ * (RGDP of USA is used as a proxy for World income). Real effective exchange rate is the weighted currency of each country to their trading country. The empirical model for this specification given as:

$$
\begin{gathered}
T B_{i t}=\beta_{0}+\beta_{1} R E E R_{i t}+\beta_{2} Y_{i t}+\beta_{3} Y_{i t} *+\varepsilon_{i t} \\
\left\{\frac{\partial T B}{\partial R E E R}>0, \frac{\partial T B}{\partial Y}<0, \frac{\partial T B}{\partial Y^{*}}>0\right\}
\end{gathered}
$$

Where $T B, Y$ and $Y^{*}$ are as defined earlier in Equation (8). The $\beta_{0}$ is a constant term and $\beta_{1}$ to $\beta_{3}$ are estimate parameters in the model and " $i$ " is a cross-section data for countries referred to, and $t$ is a time series data and $\varepsilon_{\text {it }}$ is an error term. Even though trade balance is usually measured as the 
difference between total value of exports and total value of imports, as it had been already discussed in the theoretical literature, in this study trade balance (TB) is represented by the ratio of exports to imports. This ratio, or its inverse used in many empirical investigations of trade balance and nominal exchange rate relationship as referred in ([5], [14]). [22], [26])

According to their views, the use of this ratio has the following advantages.

1. First, it is invariant to units as one measures exports and imports, in other words, whether they are in real or nominal terms or in domestic or foreign currency, it is invariant.

2. Second, the regression equation can be expressed in log linear form or constant elasticity form, which gives the Marshall-Lerner condition exactly rather than as approximation and the estimated coefficients, is elasticity.

Again to explain the expected sign of estimate, the volume of exports (imports) to a foreign country (domestic country) ought to increase as the real income and purchasing power of the trading partner (domestic economy) rises, and vice versa. Therefore, we expect $\beta_{2}<0$ and $\beta_{3}>0$. However, if the rise in real income is due to an increase in the production of importsubstitute goods, imports may decline as income increases in which case $\beta_{2}>0$ and $\beta_{3}<0$ showing ambiguous sign effect. The impact of real effective exchange rate changes on trade balance is also ambiguous, that is $\beta_{1}$ could be positive or negative. If there is a real depreciation or devaluation of the domestic currency, that is "REER" increase, then the increased competitiveness in prices for the domestic country should result in it exporting more and importing less (the "volume effect"). However, the higher "REER" also increases the value of each unit of import (the "import value effect"), which would tend to diminish the trade balance. Krugman and Obstfeld (2001) argued that in the short run import value effects prevail, whereas the volume effects dominate in the long run.

\subsection{Estimation Procedure}

\subsubsection{Panel Unit Rate Test}

In order to investigate the possibility of panel Cointegration, it is first necessary to determine the existence of unit roots in the data series. For this study the researcher have chosen the Im, Pesaran and Shin (IPS, hereafter), which is based on the Dickey-Fuller procedure. IPS proposed a test for the presence of unit roots in panels that combines information from the time series dimension with that from the cross section dimension, such that fewer time observations are required for the test to have power. IPS begins by specifying a separate $\mathrm{ADF}$ regression for each cross-section with individual effects and no time trend:

$$
\Delta y_{i t}=\alpha_{i}+\rho_{i} y_{i, t-1}+\sum_{j=1}^{p_{i}} \beta_{i j} \Delta y_{i, t-j}+\varepsilon_{i t}
$$

Where $\mathrm{i}=1 \mathrm{~N}$ and $t=1 \mathrm{~T}$

IPS use separate unit root tests for the $N$ cross-section units. Their test is based on the Augmented Dickey-fuller (ADF) statistics averaged across groups. After estimating the separate ADF regressions, the average of the $t$-statistics for $\mathrm{p}_{1}$ from the individual ADF regressions, $t_{i T_{i}}\left(p_{i}\right)$ :

$$
\bar{t}_{N T}=\frac{1}{N} \sum_{i=1}^{N} t_{i T}\left(p_{i} \beta_{i}\right)
$$

The $t$-bar is then standardized and it shown that the standardized $t$-bar statistic converges to the standard normal distribution as $\mathrm{N}$ and $\mathrm{T} \rightarrow \infty$. [28] Showed that t-bar test has better performance when $\mathrm{N}$ and $\mathrm{T}$ are small. One can reject the null hypothesis as given above when the $t_{\text {IPS }}$ statistic is smaller than a critical value from the lower tail of a standard normal distribution.

\subsubsection{Panel Cointegration Tests}

The next step is to test for the existence of a long-run Cointegration among variables using panel Cointegration tests suggested by [27-28]. The seven panels Cointegration test applied to estimated residuals from a Cointegration regression after normalizing the panel statistics with correction terms. Started by estimated residual from the hypothesized long-run regression of the following form:

$$
y_{i, t}=\alpha_{i}+\delta_{i} t+\beta_{1 i} x_{1 i, t}+\beta_{2 i} x_{2 i, t}+\ldots+\beta_{M i} x_{M i, t}+e_{i, t}
$$

for $\mathrm{t}=1, \ldots ., \mathrm{T} ; \mathrm{i}=1, \ldots, \mathrm{N} ; \mathrm{m}=1, \ldots ., \mathrm{M}$,

Where: $T$ is the number of observations over time, $N$ number of cross-sectional units in the panel, and $M$ number of regressors. In this set up, $\alpha_{i}$ is the member specific intercept or fixed effects parameter, which varies across individual cross-sectional units. The same is true of the slope coefficients and member specific time effects, $\delta_{\mathrm{i}} \mathrm{t}$. [27-28] proposed the heterogeneous panel and heterogeneous group mean panel test statistics to test for panel Cointegration. They define two sets of statistics. The first set of three statistics $Z_{\hat{\mathrm{v}}, \mathrm{N}, \mathrm{T}}, Z_{\hat{\rho} \mathrm{N}, \mathrm{T} 1}$ and $Z_{t N, T}$ is based on pooling the residuals along the within dimension of the panel. The statistics are as follows.

$$
\begin{gathered}
Z_{\hat{v}, N, T}=\left(T^{2} N^{3 / 2}\right)\left(\sum_{i=1}^{N} \sum_{t=1}^{T} \hat{L}_{11 i}^{-2} \hat{e}_{i, t 1}^{2}\right) \\
Z_{\hat{\rho} N, T \quad 1}=T \sqrt{N}\left(\sum_{i=1}^{N} \sum_{t=1}^{T} \hat{L}_{11 i}^{-2} \hat{e}_{i, t}^{2} 1\right) \\
\sum_{i=1}^{N} \sum_{t=1}^{T} \hat{L}_{11 i}^{-2}\left(\hat{e}_{i, t 1} \Delta \hat{e}_{i, t}-\hat{\lambda}_{i}\right)
\end{gathered}
$$




$$
Z_{t N, T}=\left(\widetilde{\sigma}_{N, T}^{2} \sum_{I=1}^{N} \sum_{T=1}^{T} \hat{L}_{11 i}^{-2} \hat{e}_{i, t-1}^{2}\right)^{-1 / 2} \sum_{i=1}^{N} \sum_{t=1}^{T} \hat{L}_{11 i}^{-2} \hat{e}_{i, t-1}^{2}\left(\hat{e}_{i, t-1} \Delta \hat{e}_{i, t}-\hat{\lambda}_{i}\right)
$$

Where $\hat{e}_{i, t}$ is the residual vector of the OLS estimation of Equation (9) and where the other terms are properly defined in Pederoni. The second set of statistics is based on pooling the residuals along the between dimension of the panel. It allows for a heterogeneous autocorrelation parameter across members. The statistics are as follows:

$$
\begin{gathered}
\widetilde{Z}_{\hat{\rho} N, T^{1}}=\sum_{i=1}^{N}\left(\sum_{t=1}^{T} \hat{e}_{i, t-1}^{2}\right)^{-1} \sum_{t=1}^{T}\left(\hat{e}_{i, t-1} \Delta \hat{e}_{i, t}-\hat{\lambda}_{i}\right) \\
\widetilde{Z}_{t N, T^{1}}=\sum_{i=1}^{N}\left(\sum_{t=1}^{T} \hat{e}_{i, t-1}^{2}\right)^{-1 / 2} \sum_{t=1}^{T}\left(\hat{e}_{i, t-1} \Delta \hat{e}_{i, t}-\hat{\lambda}_{i}\right) \\
\widetilde{Z}_{p p}=\sum_{i=1}^{N}\left(\sum_{t=1}^{T} S^{2} \hat{e}_{i, t-1}^{2}\right)^{-1} \sum_{t=1}^{T}\left(\hat{e}_{i, t-1} \Delta \hat{e}_{i, t}\right)
\end{gathered}
$$

These statistics compute the group mean of the individual conventional time series statistics. The asymptotic distribution of each of those five statistics can be expressed in the following form:

$$
\frac{X_{N, T}-\mu \sqrt{N}}{\sqrt{v}} \Rightarrow N(0,1)
$$

Where $X_{N, T}$ the corresponding form of the test statistics is, while $\mu$ and $v$ are the mean and variance of each test respectively. Under the alternative hypothesis, Panel $v$ statistics diverges to positive infinity. Therefore, it is a one sided test were large positive values reject the null of no Cointegration. The remaining statistics diverge to negative infinity, which means that large negative values reject the null.

$$
\begin{array}{r}
\hat{\beta}_{F M}-\beta=\left(\sum_{i=1}^{N} \hat{\Omega}_{22 i}^{2} \sum_{t=1}^{T}\left(x_{i t}-\overline{\mathbf{x}}_{i}\right)^{2}\right)^{-1} \sum_{i=1}^{N} \hat{\Omega}_{11 i}^{-1} \hat{\Omega}_{22 i}^{-1}\left(\sum_{t=1}^{T}\left(x_{i t}-\bar{x}_{i}\right) y_{i t}^{*}+T \hat{\gamma}_{i}\right) \\
y_{i t}^{*}=y_{i t}-\hat{\Omega}_{22 i}^{-1} \hat{\Omega}_{21 i} \Delta x_{i t}, \quad \hat{\gamma}_{i}=\hat{\Gamma}_{21 i}+\hat{\Omega}_{21 i}^{0}-\hat{\Omega}_{22 i}^{-1} \hat{\Omega}_{21 i}\left(\hat{\Gamma}_{22 i}+\hat{\Omega}_{22 i}^{0}\right)
\end{array}
$$

\subsubsection{Panel Fmols Estimation}

In this section, the researcher adopted FMOLS introduced in [27]. This method used due its ability to obtain asymptotically efficient consistent estimates in panel series, tackled non-exogeneity (endogeneity) and serial correlation problems (with possible heterogeneity in the short run dynamic) and takes care of unobservable. It also allows consistent and efficient estimation of Cointegration vector and addresses the problem of non-stationary regressors, as well as the problem of simultaneity biases. Since the explanatory variables are Cointegrated with a time trend, and thus a long-run equilibrium relationship exists among these variables through the panel unit root test and panel Cointegration test, we proceed to estimate the Equation (9) by panel FMOLS for heterogeneous Cointegrated panels. It is known that OLS estimation yields biased results because the regressors are endogenously determined in the $I(1)$ case. The starting point OLS as in the following Cointegrated system for panel data:

$$
y_{i t}=\alpha_{i}+x_{i t}^{\prime} \beta+e_{i t}, x_{i t}=x_{i, t-1}+\varepsilon_{i t}
$$

Where: $\xi_{i t}=\left[e_{i t}, \varepsilon_{i t}^{\prime}\right]$ is the stationary with covariance matrix $\Omega_{i}$. The estimator $\beta$ will be consistent when the error process $\omega_{i t}=\left[e_{i t}, \varepsilon_{i t}^{\prime}\right]^{\prime}$ satisfies the assumption of Cointegration between $y_{i t}$ and $x_{i t}$. The limiting distribution of panel OLS estimator depends upon nuisance parameters. Following [7], a semi-parametric correction made to the panel OLS estimator that eliminates the second order bias caused by the fact that the regressors are endogenous. [27-28] follows the same principle in the panel data context, and allows for the heterogeneity in the short run dynamics and the fixed effects. FMOLS Pedroni's estimator is constructed as follow:
$Y^{*}$ it is the endogeneity correction which take into account endogeneities in the regressors $X_{\mathrm{t}}$ associated with any cointegrating links between $X_{\mathrm{t}}$ and $\mathrm{Yt} ; Y_{\mathrm{i}}$ is the serial correlation correction terms

Where the covariance matrix $\Omega_{i}=\left[\begin{array}{ll}\Omega_{11 i} & \Omega_{12 i}^{\prime} \\ \Omega_{21 i} & \Omega_{22 i}\end{array}\right]$ can be decomposed as $\Omega_{i}=\Omega_{i}^{0}+\Gamma_{i}+\Gamma_{i}^{\prime} \quad$ where $\Omega_{i}^{0} \quad$ is the contemporaneous covariance matrix, and $\Gamma_{i}$ is a weighted sum of autocovariances. Also, $\hat{\Omega}_{i}^{0}$ denotes an appropriate estimator of $\Omega_{i}^{0}$.

\section{Results and Discussion}

\subsection{Countries Profile and Trends of Selected Variables}

From the trends depicted in figure 1 A-E of their respective real exchange rate and trade balance, it can be seen that for Ethiopia and Kenya starting from 2005 to 2014 exchange rate depreciation leads to deterioration of trade balance. However, for Tanzania and Rwanda there seems improvement in trade balance when currency depreciates more. The worsened trade balance in these countries might 
be due to increased import of goods affected by volatility of price of agricultural product, increments of goods imported for public investments, and logistic difficulties since these countries currently opened their eyes to public investments.
However, the trends do not depict any significant effect of exchange rate on trade balance, which can be solved through empirical modeling with econometrics.
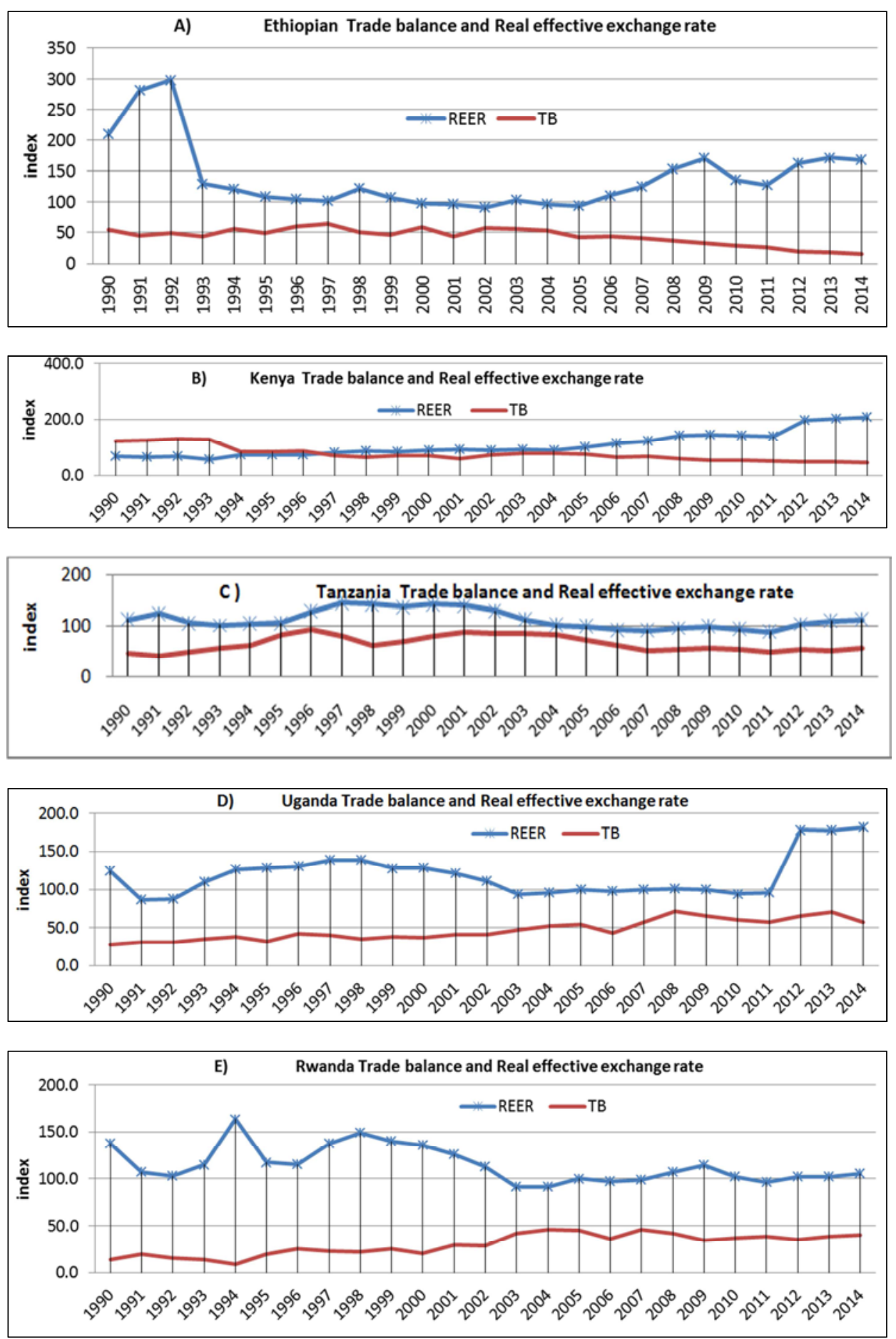

Figure 1. Trends of trade balance with real effective exchange rate in each respective country.

\subsection{Econometric Analysis}

\subsubsection{Panel Unit Root Test Result}

Table 1, presents the results of the IPS panel unit root test at level and first difference which show that the null hypothesis of a panel unit root in the level of the series cannot be rejected at various lag lengths assuming there is no time trend. Again, test for stationarity allowing for a constant plus time trend found that the null hypothesis of having panel unit root is not rejected in all series at level form and various lag lengths. Hence, the results of the IPS confirm that the variables are non-stationary at level but integrated order 1 . 
Table 1. Panel Unit Root Test - Im, Pesaran and Shin (IPS).

\begin{tabular}{lll}
\hline \multirow{2}{*}{ Variable } & Level & First order difference \\
\cline { 2 - 3 } & Constant + time trend & Constant \\
\hline LREER & $0.4760(0.680)$ & $-6.268(0.000)^{* *}$ \\
LTB & $-0.848(0.802)$ & $-8.1769(0.000)^{*}$ \\
LY* & $2.549(0.9946)$ & $-2.722(0.0032)^{*}$ \\
LY & $9.41963(1.00000)$ & $-5.53934(0.000)^{*}$ \\
\hline
\end{tabular}

Note: *, indicates rejection of the null hypothesis of a non-stationary at $1 \%$ and $5 \%$, levels of significance.

\subsubsection{Panel Cointegration Result}

The next step is to test whether the variables are Cointegrated using [27-28]. Since the variables are found to be integrated in the same order $I$ (1), we continue with the panel Cointegration tests proposed. The summary of the results of Cointegration analyses presented in Table 2 .

In constant level, we found that 6 out of 7 statistics reject null hypothesis of no Cointegration at the 5 percent level of significance for the $a d f$-statistic and group $\rho$-Statistic, while the group-adf is significant at 1 percent level. With constant plus trend level, the results indicate that 3 out of 7 statistics reject the null hypothesis of non-Cointegration at the 1 percent and 5 percent level of significance. It is shown that independent variables do hold Cointegration in the long run for a group of major developing East African countries with respect to TB. However, since all the statistics concluded in favor of Cointegration, and this, combined with the fact that according to [27] the panel non-parametric ( $t$-statistic) and parametric (adf-statistic) statistics are more reliable in constant, we conclude that there is a long run Cointegration among our variables in developing major East African countries.

Table 2. The Pedroni Panel Cointegration Test.

\begin{tabular}{lll}
\hline Test & Constant & Constant + Trend \\
\hline Panel $v$-Statistic & $1.997483^{* *}$ & 0.818157 \\
Panel $\rho$-Statistic & $-1.819876^{* *}$ & -0.016694 \\
Panel $t$-Statistic: (non-parametric) & $-4.262605^{*}$ & $-1.768787^{* *}$ \\
Panel $t$-Statistic $(a d f):($ parametric) & $-4.253292^{*}$ & $-3.276993^{*}$ \\
Group $\rho$-Statistic & -1.017392 & 0.852210 \\
Group $t$-Statistic: (non-parametric) & $-4.620437^{*}$ & -1.338638 \\
Group $t$-Statistic $(a d f):($ parametric) & $-4.608739^{*}$ & $-3.026094^{*}$ \\
\hline
\end{tabular}

Note: All statistics are from [27] where the adjusted values can be compared to the $\mathrm{N}(0,1)$ distribution. The IPS statistics are one-sided tests with a critical value of $-1.64(k<-1.64$ implies rejection of the null), except the $v$ statistic that has a critical value of $1.64(k>1.64$ suggests rejection of the null) [27]. *,** indicates rejection of the null hypothesis of no Cointegration at $1 \%$ and $5 \%$, levels of significance.

\subsubsection{Fmols Regression Result}

The last step consists in the long-run estimation of Equation (9) where the dependent variable is trade balance, and the independent variables are Real exchange rate, real GDP and real world income. The long-run coefficients estimated using between groups FMOLS panel approach are displayed in table 3 .

Table 3. FMOLS Regression.

\begin{tabular}{|c|c|c|c|c|}
\hline Variable & Coefficient & Std. Error & t-Statistic & P-Value \\
\hline LREER & -0.218035 & 0.045458 & -4.796415 & 0.000 \\
\hline LWY & 1.138127 & 0.184295 & 6.175565 & 0.000 \\
\hline LY & -1.088365 & 0.065661 & -16.57555 & 0.000 \\
\hline R-squared & 0.897554 & \multicolumn{2}{|c|}{ Mean dependent var } & 3.709707 \\
\hline Adjusted R-squared & 0.891151 & \multicolumn{2}{|c|}{ S. D. dependent var } & 0.380648 \\
\hline S. E. of regression & 0.125585 & \multicolumn{2}{|c|}{ Sum squared resid } & 1.766409 \\
\hline
\end{tabular}

0.012850 is the estimated long-run average variance of $\mathrm{e}_{\mathrm{it}}$ conditional on $\mathcal{E}_{\mathrm{it}}$, obtained from the DOLS residuals. The square root of this variance, 0.1133 , is lower than the "S. E. of the ordinal regression" value of 0.125585 , which is based on the ordinary estimator of the residual variance.

As it is seen from table 3 group estimates the coefficient of regression: the coefficient of Real exchange rate -0.218 is positive and statistically significant at 1 percent level inducing an inelastic variation. These imply that devaluation of major east African country currency would cause trade balance to deteriorate in the long-run. The inelastic behavior of exchange rate devaluation resulted is due to the countries based on oil, machine and other high priced import goods which increase the value of currency toward dollar (value effect). This result is in line with ([2], [3], [7)] and other more researchers empirically. In addition, theoretically in line with the Marshall-Lerner condition i. e. "the demand for import and export is inelastic then devaluation would further increase the deficit" [21].

Again the coefficient of real domestic income (-0.6513) is

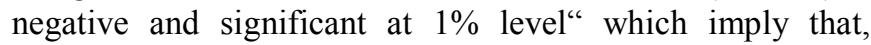
increase real domestic income of east African countries increase the volume of imports to east African countries then deteriorating trade balance. The reason is that the growth in imports in these countries under investigation clearly reflects an ever-expanding domestic demand associated with the country is improving economy. Moreover, the coefficient of real foreign income 3.152 which is both positive and significant entailing that "the volume of exports to a trading partner of major East African countries can increase as the real income and purchasing power of the trading partner rises which can improve trade balance in the long run. Although the coefficient of east African country's real income is negative and statistically significant, it is less than the coefficient of trading partner of east African real income indicating that the increase in the major trading partner of east African country's real income in comparison to that major east African real income will improve East African trade balance more. 


\section{Conclusion and Recommendation}

This study examines the effect of exchange rate on trade balance in major east African countries using the panel Cointegration approach. The unit root test (IPS) is used to confirm the stationarity of all variables before the Cointegration test can be performed. After confirming that all variables are non-stationary at level, the panel Cointegration approach is applied. Using Pedroni's, the long run Cointegration test is performed to investigate the existence of the long run Cointegration among the variables. Results obtained indicate the presence of the long run relationship between Trade balance, Real exchange rate, world income and domestic income for major developing east African countries. The study used panel group FMOLS introduced by [27] methods, in order to obtain asymptotically efficient and consistent estimates in panel series by tackling the problem of non-exogeneity and serial correlation problems and allows for greater flexibility in the presence of heterogeneity of the cointegrating vectors.

The regression result indicate that the coefficient of real domestic Income is -1.088 and coefficient of real exchange rate -0.218 is negative and statistically significant at 1 per cent level respectively for the group of panel (Ethiopia, Rwanda, Uganda, Tanzania and Kenya). It indicates that "the trade balance cannot be improved with the increasing real income of them, as their purchasing power increased, and depreciation of real exchange rate also deteriorate trade balance in the long run. In addition, the coefficient of world income is 1.138 implying that the volume of exports to a trading partner of major East African countries can increase as the real income and purchasing power of the trading partner rises, which can improve trade balance in the long run.

The coefficient of nominal exchange rate is inelastic here, which in line with the theoretical Marshall-Lerner condition i. e. "the demand for import and export is inelastic then devaluation would further increase the deficit" [21]. This is the reason behind why major east African countries are showed trade deficit. In addition, it found that, the coefficient of east real income is negative and statistically significant; it is less than the coefficient of trading partner of east African real income. These indicating that the increase in the major trading partner of east African country's real income in comparison to that major east African real income will improve East African trade balance in the long run. Generally, there is strong long run Cointegration between trade balances, nominal exchange rate, world income and domestic income of major east African countries. Therefore the researcher recommend that the policy makers of each country under this investigation i. e. Ethiopia, Rwanda, Uganda, Tanzania, and Kenya should take emphasis on devaluation of real exchange rate and selecting countries of trading partner with high income so as to increase their export performance and improve trade balance in the long run.

\section{References}

[1] Abebe Belay (2014): Journal of Economics and Sustainable Development; Exchange Rate and Trade Balance; J Curve Effect in Ethiopia.

[2] Adeyemi. A, Ogundipe Paul Ojeaga Oluwatomsin M. Ogundipe (2013): European scientific journal: Estimating the long run effects of exchange rate devaluation on the trade balance of Nigeria.

[3] Alege, Philip O (2011): Exchange rate policy and Africa's foreign trade: a panel Cointegration analysis.

[4] Anette Andersson (2010): How Does Depreciation in the Exchange Rate Affect Trade over Time.

[5] Bahmani-Oskooee, M. and Brooks, T. J. (1999): Bilateral JCurve between U. S. and her Trading Partners.

[6] Brown, W. B., \& Hogendorn, J. S. (2000): International Economics - In the Age of globalization Peterborough: Broadview Press.

[7] Chee-Wooi, H., \& Tze-Haw, C. (2008): Examining Exchange rates exposure, J-curve and the Marshall-Lerner Condition for high frequency trade series between China and Malaysia.

[8] Demirden \& Pastine, I. (1995): Flexible Exchange rates and the J-curve: An alternative approach.

[9] Daniels, J. P, \& VanHoose, D. (2004): International Monetary and Financial.

[10] Dornbusch, R., Fischer, S., \& Startz, R. (2004): Macroeconomics (ninth edition.). New York: McGraw-Hill.

[11] Economics (third edition): N. Thompson South-Western College Publishing.

[12] Eric Kamoto (2010): the j-curve effect on the trade balance in Malawi and South Africa.

[13] Elif Guneren (2014): European scientific journal: The effect of exchange rates on Exports and imports of emerging Countries.

[14] Guptar-Kapoor, Anju and Ramakrishnan, Uma (1999): Is There a J-Curve? A New Estimation for Japan, International Economic Journal.

[15] Grephas O. Ogutu (2014): International institute of social study: Effects of the real exchange rate on the trade balance in Kenya.

[16] Glenville Rawlins (2008): Journal of Applied Business and Economics Montclair State University. Using Currency Devaluations as a Tool to Improve the Trade Balance: The Experience of Central America and the Caribbean.

[17] Gartner, M. (1993): Macroeconomics under flexible exchange rate. Manchester.

[18] Hacker, R. S., \& Hatemi-J, A. (2003): Is the J-curve effect observable for small North European economies?

[19] Isard, P. (1995): Exchange rate economics. Cambridge: Cambridge University Press? 
[20] Khan, M. and M. Knight (1988): Import Compression and Export Performance in Developing Countries. Review of Economics and Statistics.

[21] Lerner A. P. (1944): The Economics of Control - Principles of Welfare Economics. New York: The MacMillian Company.

[22] Lal, Anil K. and Lowinger, Thomas C. (2001): "J-Curve: Evidence from East Asia," manuscript presented at the 40th Annual Meeting of the Western Regional Science Association February 2001 in Palm Springs.

[23] Marshall, A. (1923): Money Credit and Commerce. London: MacMillian \& Co. Ltd.

[24] Marshall, A. (1997): Money Credit and Commerce. Bristol/Tokyo.

[25] Moses Joseph (2013): International Journal of Business and Economics Research: Analysis the determinants of trade balance: Case study of Tanzania.
[26] Onafowora, O. (2003): Exchange rate and trade balance in East Asia: Is there a J-curve, Economic Bulletin.

[27] Pedroni, P. (1999): Critical Values for Cointegration Tests in Heterogeneous Panels with Multiple Regressors," Oxford Bull.

[28] Pedroni, P. (2000): Fully Modified OLS for Heterogeneous Cointegration Panel in Nonstationary Panels, Panel Cointegration and Dynamic Panels, Advances in Ec.

[29] Rawlins and Praven (1993): Devaluation and the Trade Balance: The Recent Experience of Selected African Countries.

[30] Vivek K. and Vishal M (2012): Reserve Bank of India Occasional Papers Is India's Trade Balance Sensitive to Real Exchange Rates? A Bilateral Trade Data Analysis.

[31] Zhang, W-B (2008): International trade theory- Capital, knowledge, economic, structure, money and prices over time, Berlin Heidelberg, Springer. 